\title{
Halocline structure in the Canada Basin of the Arctic Ocean
}

\author{
Koji Shimada, Motoyo Itoh, and Shigeto Nishino \\ Institute of Observational Research for Global Change, Japan Agency for Marine-Earth Science and Technology, \\ Yokosuka, Japan
}

\author{
Fiona McLaughlin and Eddy Carmack \\ Institute of Ocean Sciences, Sidney, British Columbia, Canada
}

Andrey Proshutinsky

Woods Hole Oceanographic Institution, Woods Hole, Massachusetts, USA

Received 28 August 2004; revised 31 October 2004; accepted 3 January 2005; published 5 February 2005.

[1] We examine the varieties and spatial distributions of Pacific and Eastern Arctic origin halocline waters in the Canada Basin using 2002-2003 hydrographic data. The halocline structure in the Canada Basin is different from the Eastern Arctic halocline because it includes fresher Pacific Winter Waters that form a "cold halostad" which lies above the Eastern Arctic origin lower halocline waters. The structure of the halostad in the Canada Basin, however, is not spatially uniform, and depends on the pathway and history of the source water. Pacific Winter Water entering through the Bering Strait becomes salty due to sea ice formation and this, in turn, is dependent on the occurrence and distribution of polynyas. In particular, saline water from the eastern Chukchi Sea forms thick halostad and causes depression of the isohalines in the southern Canada Basin. This depression influences thermohaline structure of the oceanic Beaufort Gyre. Citation: Shimada, K., M. Itoh, S. Nishino, F. McLaughlin, E. Carmack, and A. Proshutinsky (2005), Halocline structure in the Canada Basin of the Arctic Ocean, Geophys. Res. Lett., 32, L03605, doi:10.1029/ 2004GL021358.

\section{Introduction}

[2] The Arctic cold halocline, consisting of waters near the freezing temperature, has been recognized as an important feature of the Arctic Ocean [Aagaard et al., 1981]. It shields the surface mixed layer from the upward flux of heat and salt in the underlying Atlantic layer. Hence describing the composition and variability of Arctic cold halocline waters are crucial components in understanding Arctic change. The formation of the halocline in the Eastern Arctic basins has been described [Rudels et al., 1996]. In contrast, the halocline in the Canada Basin is more complex, reflecting inputs of both Pacific- and Atlantic-origin waters. Pacific Winter Water, centered near $\mathrm{S}=33.1$, has long been recognized as primary component of the western Arctic halocline [Coachman et al., 1975]. Pacific Winter Water through the Bering Strait [Woodgate and Aagaard, 2005] was modified in the coastal polynya between Point Barrow and Cape Lisburne (e.g., increased salinity due to ice formation) [Cavalieri and Martin, 1994; Weingartner et al., 1998; Martin et al., 2004]. However, the spatial distri-

Copyright 2005 by the American Geophysical Union. 0094-8276/05/2004GL021358\$05.00 bution of this more saline water in the Canada Basin and its role in the formation of basin-scale oceanic structures has not yet been reported. Below the Pacific sources near $\mathrm{S}=$ 34.0 , two types of halocline water originating from the Eastern Arctic have been observed; oxygen poor water [Jones and Anderson, 1986], and rich water [McLaughlin et al., 2004]. We here examine the varieties and distribution of halocline waters in the Canada Basin delivered from both the Pacific and the Eastern Arctic using new hydrographic data from 2002-2003. We also discuss a possible role of the Pacific origin halocline waters on the thermohaline structure of the oceanic Beaufort Gyre [Proshutinsky et al., 2002].

\section{Data}

[3] Hydrographic data presented here were collected aboard the CCGS Louis S. St-Laurent (LSSL) from August to September in 2002 and 2003 and the R/V Mirai from September to October in 2002 as part of a Japan-Canada project called the Joint Western Arctic Climate Studies (JWACS) and a US-Canada project called the Beaufort Gyre Freshwater Experiment (BGFE). Locations of the CTD and XCTD stations are illustrated in Figure 1. Salinity samples for calibrating CTD data were analyzed on a Guildline Autosal salinometer. Dissolved oxygen samples were analyzed using Winkler titration method and used to calibrate the oxygen sensor data. The accuracies of the CTD salinity and the dissolved oxygen sensor data are: $\mathrm{S}=$ $\pm 0.0007 \mathrm{psu}$ and $\mathrm{DO}= \pm 0.042 \mathrm{~mL} / \mathrm{L}$ for the $2002 \mathrm{LSSL}$ data; $\mathrm{S}= \pm 0.0008 \mathrm{psu}$ and $\mathrm{DO}= \pm 0.085 \mathrm{~mL} / \mathrm{L}$ for the 2003 LSSL data; and $\mathrm{S}= \pm 0.0009 \mathrm{psu}$ and $\mathrm{DO}= \pm 0.045 \mathrm{~mL} / \mathrm{L}$ for the $2002 R / V$ Mirai data.

\section{Varieties of Halocline Water in the Canada Basin}

[4] The halocline structure is not uniform across the Arctic Ocean, and the differences between the Canada Basin and Makarov Basin haloclines are shown in Figure 2. In the Makarov Basin (black color) the well-known cold halocline is evidenced by the single "cold halocline" structure. In contrast the Canada Basin has a more complex salinity profile between the surface mixed layer and Atlantic Water. The salinity stratification in this range is much weaker than that in the Makarov Basin (Figure 2b). These characteristics indicate the presence of Pacific Winter Waters and suggest 


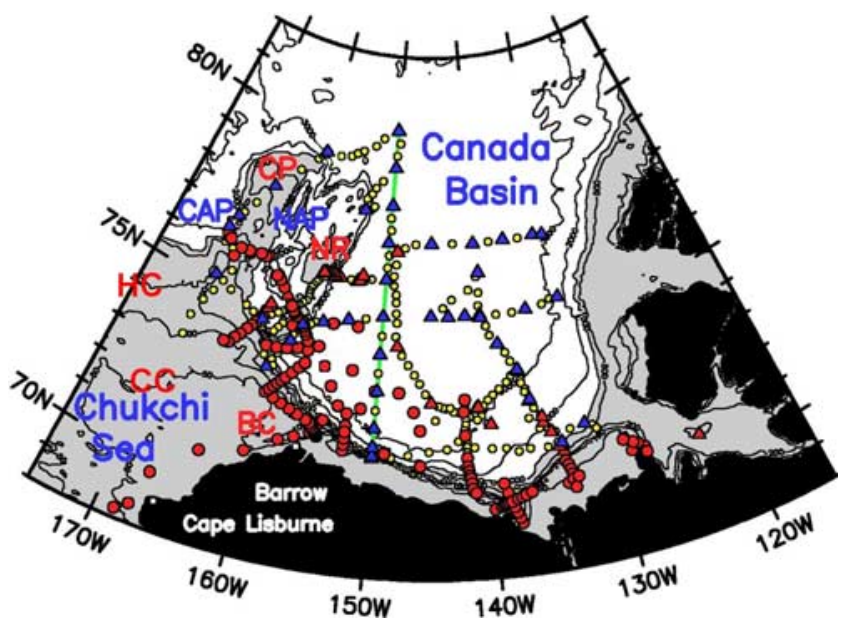

Figure 1. Study area and CTD/XCTD stations. The area shallower than $1000 \mathrm{~m}$ is shaded. Red circles identify R/V Mirai 2002 CTD stations. Red and green triangles are CTD stations of LSSL 2002 and 2003 respectively. Yellow circles are XCTD stations in 2002 and 2003. There are sub-basins; Chukchi Abyssal Plain (CAP) and Northwind Abyssal Plain (NAP) divided by ridges; Chukchi Plateau (CP) and Northwind Ridge (NR). Barrow Canyon, Central Channel and Herald Canyon are marked as $\mathrm{BC}, \mathrm{CC}$ and $\mathrm{HC}$ respectively. Green line along $150^{\circ} \mathrm{W}$ indicates the section shown in Figures 2 and 4. that the concept of the cold halocline that has been discussed in the Eastern Arctic basins is not applicable in the Canada Basin. In the following discussion the term "halostad" is used to refer to the region of the weak stratification. Below the halostad, the lower halocline waters originating from the Eastern Arctic are classified into two types (Figures 2c and $2 \mathrm{~d}$ ). These characteristics define the principle varieties of source waters that comprise the Canada Basin halocline, as discussed in detail below. Here we focus on the winter waters within the western Arctic halocline. Halocline waters originating from the Pacific Summer Water were investigated by Shimada et al. [2001].

\subsection{Pacific Origin Halocline Source Water}

[5] The structure of salinity stratification in the Canada Basin is classified into two types. Data from a section along $150^{\circ} \mathrm{W}$ show that the halostad north of $77^{\circ} \mathrm{N}$ occupies a depth range from the upper salinity breaks at $50 \mathrm{~m}$ to the lower breaks at $120 \mathrm{~m}$ (Figure $2 \mathrm{~b}$ ). On the section south of $77^{\circ} \mathrm{N}$, the halostad becomes thicker to the lower salinity breaks at $170 \mathrm{~m}$ (Figure $2 \mathrm{~b}$ ). In addition the salinity range of the halostad has slightly increased from $32.0<\mathrm{S}<33.2$ to $32.0<\mathrm{S}<33.5$. These two distinct structures would be associated with different source water histories dependent on salt production in the Chukchi Sea. For example, the time series data of moorings in the Barrow Canyon (Figure 3) downstream of the coastal polynya between the Cape Lisburne and Point Barrow, showed production and delivery of more saline water greater than $\mathrm{S}=34$ with nearfreezing temperature during late winter and spring into the (a) Potential Temperature

(b) Salinity
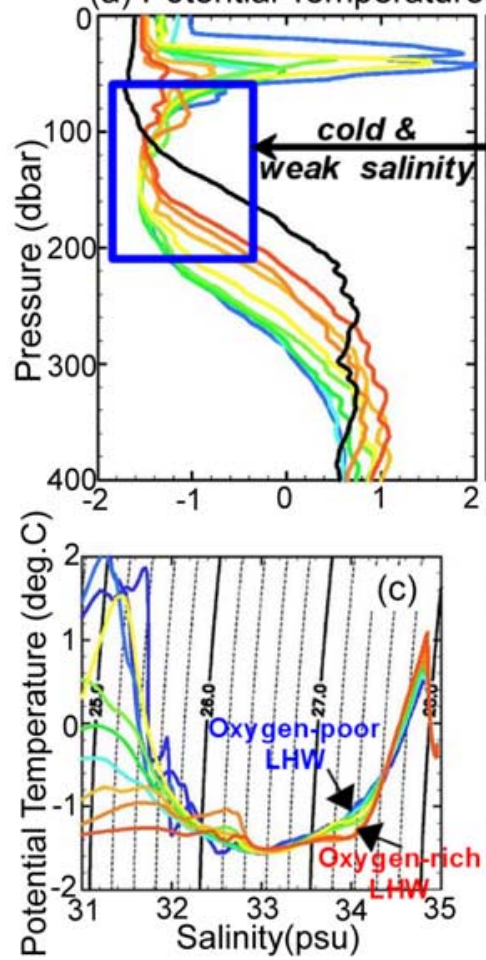
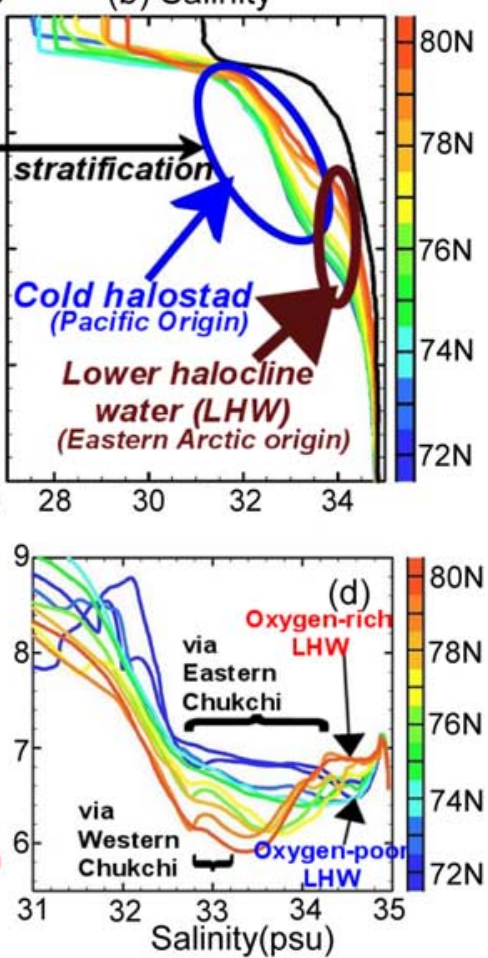

Figure 2. Vertical profiles of (a) temperature and (b) salinity along $150^{\circ} \mathrm{W}$ section (colored) and in Makarov Basin (black) at $84^{\circ} 6^{\prime} \mathrm{N}, 174^{\circ} 59^{\prime} \mathrm{W}$ from AOS94 expedition in 1994. (c) Potential temperature-salinity and (d) oxygen-salinity correlations along $150^{\circ} \mathrm{W}$ section in Figure 1. 


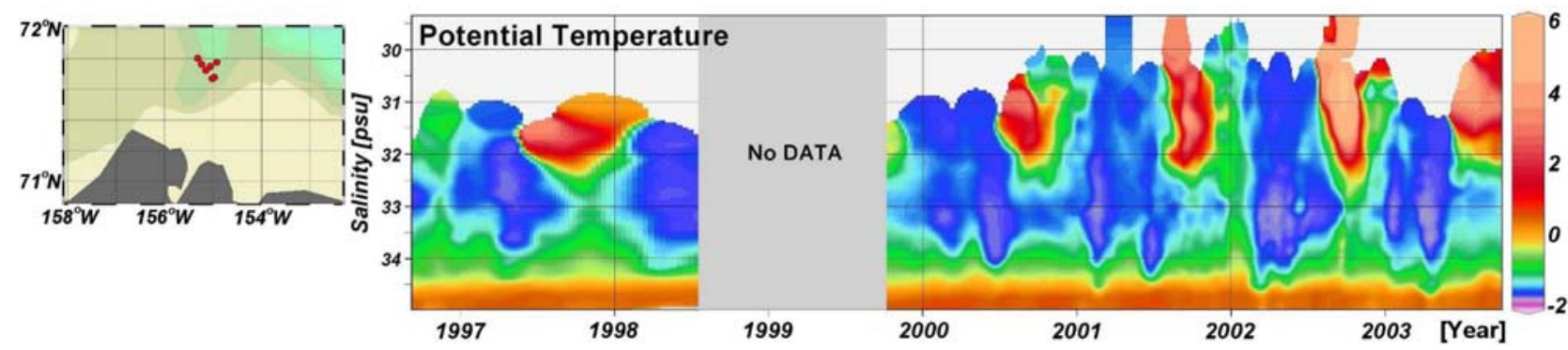

Figure 3. Time series of potential temperature in the Barrow Canyon from mooring data from 1996 to 2003. Locations of mooring are indicated in the map.

Canada Basin. The more saline water will have higher oxygen concentration than the Pacific Winter Water transiting the western Chukchi Sea [Weingartner et al., 1998], owing to less biological consumption on the Chukchi Shelf due to short advective distance from the polynya region to the basin. In the basin the oxygen concentrations at $32.0<$ $\mathrm{S}<34.0$ are higher south of $77^{\circ} \mathrm{N}$ than to the north (Figure 2d). This implies that influence of the oxygen-rich newly-ventilated saline water is dominant on the southern part. Consequently, the thick haolstad structure is established on the section south of $77^{\circ} \mathrm{N}$. On the other hand, the Pacific Winter Water with less salt production on the upstream western Chukchi Shelf is dominant on the northern part.

\subsection{Lower Halocline Waters in the Canada Basin}

[6] Oxygen concentrations in the salinity range of lower halocline $34.0<\mathrm{S}<34.7$ on the northern part of the $150^{\circ} \mathrm{W}$ section (Figure 2d) are higher than on the southern part. This oxygen poor property in the southern part of the section is the same property as the "lower halocline water" described by Jones and Anderson [1986]. The higher values observed in the northern part imply that there is another source of ventilated water exterior to the Canada Basin. McLaughlin et al. [2004] observed a local oxygen maximum in the salinity range of lower halocline water near $\mathrm{S}=33.8$ at 1998 SHEBA/JOIS stations located over the outer Chukchi Plateau. A possible origin for the oxygen-rich water could be the convective halocline water in the Eurasian Basins discussed by Steele and Boyd [1998]. During 2002-2003, however, the oxygen maximum water was observed at $\mathrm{S}=$ $34.2-34.3$ north of the Chukchi Plateau. This salinity is slightly higher than that noted in the 1998 SHEBA/JOIS data by McLaughlin et al. [2004] suggesting recent changes in Eastern Arctic source waters. Since mid-1990s the surface mixed layer salinity in the Eurasian Basins increased to $\mathrm{S}=$ 34.2 associated with the retreat of the cold halocline [Steele and Boyd, 1998]. The difference of the salinity value at the local oxygen maximum between 1998 and 2002-2003 north of the Chukchi Plateau might thus be linked to recent changes in the Eastern Arctic Basin.

\section{Spatial Distribution of Halocline Waters in the Canada Basin}

[7] First, we examine the spatial distribution of halocline waters using vertical sections of temperature, oxygen with isohalines along the $150^{\circ} \mathrm{W}$ section (Figure 4). In the cold layer between $\mathrm{S}=32.5$ and 33.5, oxygen-rich water occupies the southern Canada Basin spreading northward from the slope. Depressions of isohalines $32.5<\mathrm{S}<33.5$ south of $77^{\circ} \mathrm{N}$ in Figure 4 accompany a thick cold layer with weak salinity stratification, except upwelling region on the slope near $72^{\circ} \mathrm{N}$. This suggests that the depressions of the isohalines are not only caused by wind forcing, i.e., Ekman convergence, but also by the volumetric injection of Pacific Winter Water. This thermohaline forcing would affect the baroclinic structure of the anticyclonic oceanic Beaufort gyre [Proshutinsky et al., 2002].

[8] Incorporating all the 2002-2003 data, horizontal maps of oxygen on $\mathrm{S}=33.1$ and $\mathrm{S}=34.3$, corresponding to the core salinities of Pacific and Eastern Arctic origin halocline waters, respectively are shown in Figure 5. On S = 33.1, highest oxygen concentration is observed in the vicinity of the Barrow Canyon. High oxygen waters are also there on $\mathrm{S}=34.3$. This implies that Pacific Winter Water via the eastern Chukchi Shelf acquires a broad salinity range due to occasional salt production, and subsequently spreads into the southern Canada Basin from the northeastern Chukchi slope. In contrast, in the region downstream of the Herald Canyon, oxygen on $\mathrm{S}=34.3$ is lower, even though oxygen on $\mathrm{S}=33.1$ remains high (Figure 5), suggesting that the Pacific Winter Water from the western Chukchi Sea results in narrow salinity range and restricted ventilation. These differences in the salinity range of Pacific Winter Waters are clearly found in salinityoxygen correlation in the basin (Figure 2d). In the region north of $77^{\circ} \mathrm{N}$, narrow oxygen maxima is centered at $\mathrm{S}=$ 33.1. This suggests that the majority of Pacific Winter Water
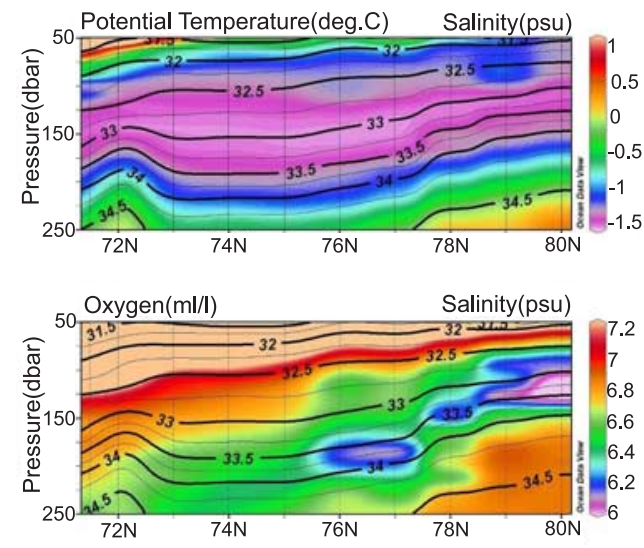

Figure 4. Vertical Section of (a) potential temperature and (b) oxygen with isohalines along $150^{\circ} \mathrm{W}$ section in Figure 1. 
entering via the western Chukchi Sea spreads into the basin north of $77^{\circ} \mathrm{N}$. However, in the region south of $77^{\circ} \mathrm{N}$ the salinity-oxygen correlation shows broad oxygen maxima in the salinity range of $33.1<\mathrm{S}<34.3$.

[9] From a basin scale point of view, on $\mathrm{S}=34.3$ (Figure 5) oxygen-rich water occupies northern half of the observed area. The highest concentration was observed on the northern flank of the Chukchi Plateau. The high oxygen water spreads southeastward toward the Canadian Beaufort Sea, suggesting an anticyclonic circulation at this isohaline. Along the shelf slope from the Chukchi Abyssal Plain into the Canadian Beaufort Sea, relatively high oxygen water occurs in the vicinity of Barrow Canyon (Figure 5). The appearance of this local high oxygen pool at $\mathrm{S}=34.3$ is not associated with the high oxygen water from the north, but reflects the influence of more saline Pacific Winter Water via Barrow Canyon.

\section{Summary and Discussion}

[10] The properties and distributions of distinct halocline waters in the Canada Basin halocline are investigated using hydrographic data obtained in 2002 and 2003. The spreading pattern of the distinct halocline waters is summarized in Figure 6. Here the halocline structure in the southern Canada Basin is characterized, in a sense, by a double halocline with a "cold halostad" formed by the volumetric injection of Pacific Winter Water, and is thus distinct from the Eastern Arctic halocline structure which is characterized by a single "cold halocline". The oceanic role of the halostad in the Canada Basin is identical to that of the subtropical mode water in mid-latitude oceans [Hanawa and Talley, 2001].

[11] Pacific origin halocline source waters are classified into two types; the less saline inputs of water entering via the western Chukchi Sea and the more saline water produced by ice formation in the eastern Chukchi Sea.

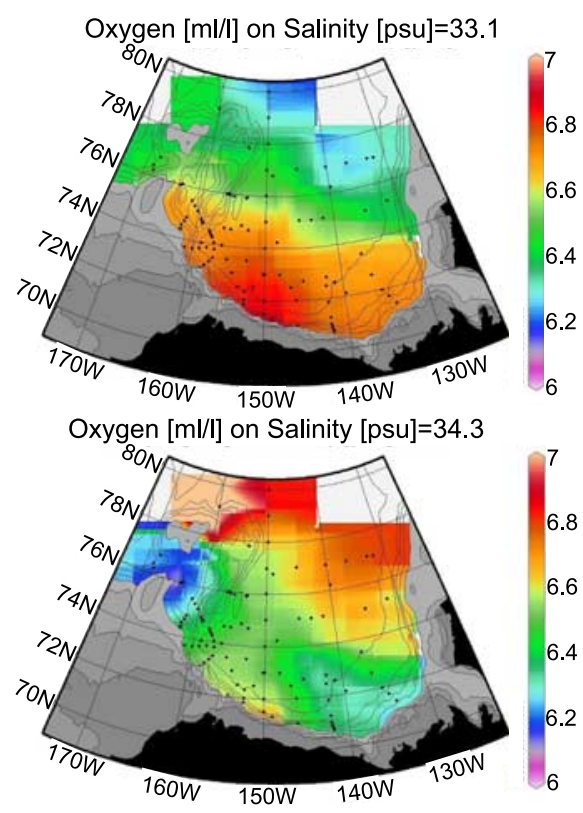

Figure 5. Horizontal map of oxygen on $\mathrm{S}=33.1$ and on $\mathrm{S}=34.3$.

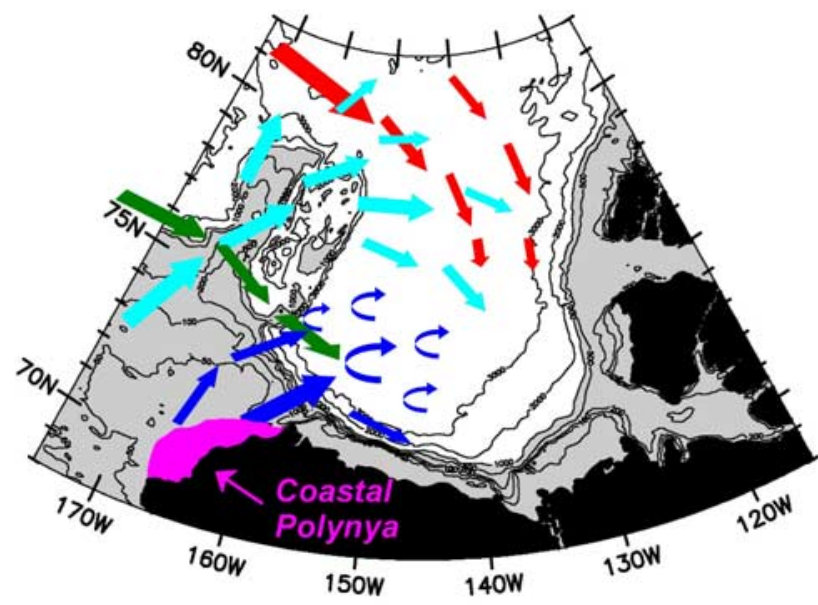

Figure 6. Schematic image of spreading of different halocline waters in the Canada Basin. Cyan is Pacific Winter Water less salt inputs via western Chukchi Sea, blue is the saline Pacific Winter Water via Eastern Chukchi Sea, red is oxygen-rich lower halocline water from outside of the Canada Basin and green is oxygen-poor lower halocline water delivered along the slope from west.

The former type spreads in the Canada Basin north of $77^{\circ} \mathrm{N}$. The later one with more saline winter water spreads in the Canada Basin south of $77^{\circ} \mathrm{N}$ and establishes the thick halostad yielding deep depression of isohalines. This thermohaline forcing, i.e., low potential vorticity forcing, acts to deform the baroclinic structure of oceanic Beaufort Gyre.

[12] Below the halostad, two types of lower halocline waters are also identified in the Canada Basin. One is oxygen-poor halocline water delivered along the Siberian/ Chukchi slope from west and this type occupies the southern Canada Basin. The other oxygen-rich halocline water from Eastern Arctic observed near $\mathrm{S}=34.3$ and dominates the northern Canada Basin. Some of this oxygen-rich lower halocline water spreads southeastward toward the Canadian Beaufort Sea. The pathway of the oxygen-rich lower halocline water across the Lomonosov and Mendeleyev Ridges into the Canada Basin is still uncertain due to fragmental data in the Siberian side of the Makarov Basin.

[13] Acknowledgments. We are greatly indebted to the officers and crew of the R/V Mirai and CCGS Louis S. St-Laurent, and to the scientists and technicians who supported field expeditions (SCICEX, AOS94, NOGAP, SHEBA/JOIS, JWACS/BGFE). This work was funded in part by the Japan Agency for Marine-Earth Science and Technology, the Fisheries and Oceans Canada, and the U.S. National Science Foundation.

\section{References}

Aagaard, K., L. K. Coachman, and E. Carmack (1981), On the halocline of the Arctic Ocean, Deep Sea Res., Part A, 28, 529-545.

Cavalieri, D. J., and S. Martin (1994), The contribution of Alaskan, Siberian, and Canadian coastal polynyas to the cold halocline layer of the Arctic Ocean, J. Geophys. Res., 99, 18,343-18,362.

Coachman, L. K., K. Aagaard, and R. B. Tripp (1975), Bering Strait: The Regional Physical Oceanography, 172 pp., Univ. of Wash. Press, Seattle, Wash.

Hanawa, K., and L. D. Talley (2001), Mode waters, in Ocean Circulation and Climate, edited by G. Siedler, J. Church, and J. Gould, chap. 5.4., pp. 373-386, Elsevier, New York.

Jones, E. P., and L. G. Anderson (1986), On the origin of the chemical properties of the Arctic Ocean halocline, J. Geophys. Res., 91, 10,75910,767 . 
Martin, S., R. Drucker, R. Kwok, and B. Holt (2004), Estimation of the thin ice thickness and heat flux for the Chukchi Sea Alaskan coast polynya from Special Sensor Microwave/Imager data, 1990-2001, J. Geophys. Res., 109, C10012, doi:10.1029/2004JC002428.

McLaughlin, F. A., E. C. Carmack, R. W. Macdonald, H. Melling, J. H. Swift, P. A. Wheeler, B. F. Sherr, and E. B. Sherr (2004), The joint roles of Pacific and Atlantic-origin waters in the Canada Basin, 1997-1998, Deep Sea Res., Part I, 51, 107-128.

Proshutinsky, A., R. H. Bourke, and F. A. McLaughlin (2002), The role of the Beaufort Gyre in Arctic climate variability: Seasonal to decadal climate scales, Geophys. Res. Lett, 29(23), 2100, doi:10.1029/2002GL015847.

Rudels, B., L. G. Anderson, and E. P. Jones (1996), Formation and evolution of the surface mixed layer and the halocline of the Arctic Ocean, J. Geophys. Res., 101, 8807-8821.

Shimada, K., E. Carmack, K. Hatakeyama, and T. Takizawa (2001), Varieties of shallow temperature maximum waters in the western Canadian Basin of the Arctic Ocean, Geophys. Res. Lett., 28, 3441-3444.

Steele, M., and T. Boyd (1998), Retreat of the cold halocline layer in the Arctic Ocean, J. Geophys. Res., 103, 10,419-10,435.
Weingartner, T. J., D. J. Cavalieri, K. Aagaard, and Y. Sasaki (1998), Circulation, dense water formation, and outflow on the northeast Chukchi shelf, J. Geophys. Res., 103, 7647-7661.

Woodgate, R. A., and K. Aagaard (2005), Revising the Bering Strait freshwater flux into the Arctic Ocean, Geophys. Res. Lett., 32, L02602, doi:10.1029/2004GL021747.

E. Carmack and F. McLaughlin, Institute of Ocean Sciences, Sidney, British Columbia, Canada V8L 4B2. (mclaughlinf@pac.dfo-mpo.gc.ca; carmacke@pac.dfo-mpo.gc.ca)

M. Itoh, S. Nishino, and K. Shimada, Institute of Observational Research for Global Change, Japan Agency for Marine-Earth Science and Technology, Yokosuka 237-0061, Japan. (shimadak@jamstec.go.jp; motoyo@jamstec. go.jp; nishinos@jamstec.go.jp)

A. Proshutinsky, Woods Hole Oceanographic Institution, MS 29, 360 Woods Hole Road, Woods Hole, MA 02543, USA. (aproshutinsky@) whoi.edu) 